\title{
A guinea pig model for cytomegalovirus congenital infection: dose-effect and vertical transmission rate Guillaume Benoist*1, Yves Ville ${ }^{1}$, Christine Rouzioux ${ }^{2}$, Anne-Lise Delezoide ${ }^{3}$, Pierre Flori ${ }^{4}$ and Mariane Leruez-Ville ${ }^{2}$
}

\author{
Address: ${ }^{1}$ Service de Gynécologie Obstétrique, Hôpital de Poissy-St-Germain, 78300 Poissy, ${ }^{2}$ Laboratoire de Virologie, EA 36-20 Université Paris- \\ Descartes, Faculté de Médecine de Necker, CHU Necker-Enfants-Malades, AP-HP, Paris, France, ${ }^{3}$ Laboratoire de biologie du développement, \\ Hopital robert Debré, AP-HP, 75935 Paris cedex 19, France and ${ }^{4}$ Laboratoire de biologie du développement, Hopital Robert Debré, AP-HP, 75935 \\ Paris cedex 19, France \\ * Corresponding author
}

from Fourth Dominique Dormont International Conference. Host-Pathogen Interactions in Chronic Infections Paris, France. 13-15 December 2007

Published: 9 April 2008

Retrovirology 2008, 5(SuppI I):PI doi:I0.I I86/I742-4690-5-SI-PI

This abstract is available from: http://www.retrovirology.com/content/5/SI/PI

(c) 2008 Benoist et al.; licensee BioMed Central Ltd.

\section{Backgrounds and objectives}

Animal models are necessary to test new antiviral drugs to prevent CMV materno foetal transmission [1]. Among the small animal CMV models, the guinea pig CMV (GPCMV) has the ability to cross the placenta [2], causing disease in utero $[3,4]$. The objective was to study the relation between inoculum doses of guinea pig cytomegalovirus (GPCMV) and the natural history of congenital disease in the pregnant guinea pig model, by means of updated ultrasound and virological methods.

\section{Methods}

1) Development of ultrasound examination for precise assessment of the gestational age based on fetal crownrump length $(\mathrm{CRL})$ measure.

2) Development of a real time PCR Taqman ${ }^{\circledR}$ GPCMV based on the amplification of a sequence of the UL83 gene and determination of its sensitivity.

3) Subcutaneous administration at mid-gestation of two doses $\left(10^{6}\right.$ DI50 in group 1 and $10^{8}$ DI50 in group 2 of GPCMV strain obtained by cell culture in CMV-seronegative pregnant Hartley strain guinea pigs. Serial sacrifice of the animals were performed in the second part of the gestation up to collect maternal tissues, maternal blood, amniotic fluid, placenta and fetal tissues and to determine the GPCMV load. Conventional histological examination of the fetal infected tissues was performed.

\section{Results}

18 pregnant guinea pigs were included in group 1 and nine in group 2 .

1) Ultrasound examinations allowed the diagnosis of gestations in the totality of the cases. A growth curve of fetuses based on CRL was built.

2) The real time PCR GPCMV developed had sensitivity at $50 \%$ and $95 \%$ of 200 copies $/ \mathrm{mL}$ and 2500 copies $/ \mathrm{mL}$ respectively, with a wide linear ranges up to $10^{6}$ copies/ $\mathrm{mL}$.

3) CMV infections were observed in 14/18 females in group 1 and in $9 / 9$ females in group 2 .

GPCMV maternal viremia was observed in $28 \%$ and $70 \%$, the median viral load was 100 and 700 copies $/ \mathrm{ml}$ in groups 1 and 2 respectively. The proportion of female with at least one infected fetus in their litter was $0 / 18$ and $2 / 9(22.22 \%)$ in group 1 and 2 respectively $(\mathrm{p}=0.103$, Fisher Exact Test). 


\section{Conclusions}

We developed an effective animal model using ultrasound for determination of gestational age and a sensitive real time GPCMV PCR for the diagnosis of GPCMV neonatal infections. The acute infection with GPCMV in the guineapig was reproduced in this model with materno-foetal transmission. We show that the kinetics and the intensity of the primary infection in the pregnant females as well as the vertical transmission rate are related to the inoculum's viral load. This model will be useful for further antiviral CMV drug assays.

\section{References}

I. Schleiss MR: Nonprimate models of congenital cytomegalovirus (CMV) infection: gaining insight into pathogenesis and prevention of disease in newborns. Ilar J 2006, 47(I):65-72.

2. Enders AC: A Comparative Study of the Fine Structure of the Trophoblast in Several Hemochorial Placentas. Am J Anat 1965, I 1 6:29-67.

3. Schleiss MR, Bourne N, Bravo FJ, Jensen NJ, Bernstein DI: Quantitative-competitive PCR monitoring of viral load following experimental guinea pig cytomegalovirus infection. J Virol Methods 2003, I08(I): I03-III.

4. Griffith BP, Hsiung GD: Cytomegalovirus infection in guinea pigs. IV. Maternal infection at different stages of gestation. J Infect Dis 1980, I4I(6):787-793.

Publish with Bio Med Central and every scientist can read your work free of charge

"BioMed Central will be the most significant development for disseminating the results of biomedical research in our lifetime. "

Sir Paul Nurse, Cancer Research UK

Your research papers will be:

- available free of charge to the entire biomedical community

- peer reviewed and published immediately upon acceptance

- cited in PubMed and archived on PubMed Central

- yours - you keep the copyright

Submit your manuscript here:

http://www.biomedcentral.com/info/publishing_adv.asp 